\title{
Clinical Negative Pressure Measurement after Border Molding Procedure
}

\author{
Dobromira A. Shopova, Diyan Slavchev \\ Department of Prosthetic Dentistry, Faculty of Dental Medicine, Medical University of Plovdiv, Plovdiv, Bulgaria
}

Corresponding author: Dobromira A. Shopova, Department of Prosthetic Dentistry, Faculty of Dental Medicine, Medical University of Plovdiv, 3 Hristo Botev Blvd., 4000 Plovdiv, Bulgaria; E-mail: dent.shopova@gmail.com; Tel.: +359 887417078

Received: 14 Nov 2019 Accepted: 16 Jan 2020 Published: 30 Sep 2020

Citation: Shopova DA, Slavchev D. Clinical negative pressure measurement after border molding procedure. Folia Med (Plovdiv) 2020;62(3):578-84. doi: 10.3897/folmed.62.e48464.

\begin{abstract}
Introduction: Border molding of the custom tray's edge is an important stage in the treatment of an edentulous jaw that determines the stability of prosthesis at rest and function. Solid, thermoplastic and silicon impression materials may be used in border molding. After bolder molding procedure, the negative pressure between the custom tray and the prosthetic field is created. This is an informal indication for a good impression.
\end{abstract}

Aim: To compare the negative pressure created after border molding procedure with different impression materials.

Materials and methods: 35 patients (17 men and 18 women) aged 51 to 87 years with a complete edentulous upper jaw were examined. New clinical method for negative pressure measurement was created. We used a special custom tray with palatal adaptor and a pump. Two groups of impression materials were tested: thermoplastic (Kerr impression compound green sticks, GC Iso functional sticks) and silicones (Detaseal function, Sta-seal f). Statistical analysis was performed using ANOVA, confirmed by the absolute value analysis used to compare negative results, and a log transformation analysis for greater precision and also for negative data comparison.

Results: A statistically significant difference was found between the two thermoplastic materials - GC Iso functional sticks and Impression compound green sticks. The mean group difference between these materials was 0.049 bars. There was no statistically significant difference between the other groups of materials.

Conclusion: Quantitative measurement of negative pressure, created between the custom tray and the prosthetic field is entirely possible under clinical conditions.

\section{Keywords}

edentulous maxilla, negative pressure

\section{INTRODUCTION}

Border molding of the custom tray's edge is an important stage in the treatment of an edentulous jaw that determines the stability of prosthesis at rest and function. Applying the border molding reduces the deformation of the alveolar crest and the border of the soft tissues, resulting in an increased retention and stability.

Impressions for complete dentures fabrication can be made by minimal (mucostatic), maximal (biting) and functional pressure. Minimal pressure technique does not interfere with the blood supply and tissue-fluid circulation, but the border zone cannot be impressed precisely. The technique with maximal pressure improves the border's area shaping. The functional pressure technique is a successful solution to the problems with harmful pressure and incorrect impressing of the border zones. ${ }^{1}$ Selective pressure concept is invented by Boucher in 1950. It combines the mucosta- 
tic and mucocompressive techniques. The mucosa of the alveolar ridges is thicker and can withstand the pressure, whereas the mucosa, covering the palate and a midline is thin and non-resilient. ${ }^{2}$ The greatest value was measured in the midline, followed by palate slopes and the alveolar ridge. ${ }^{3}$ According to another study, the greatest value was in the incisive papilla, the distal part of the midline and the deepest part of the palate. ${ }^{4}$ According to this concept, the custom trays were made with different design to relieve the stress-bearing area - with relief (vent) holes, spacers, stops in the canine and first molar zones. ${ }^{5}$

The pressure values depend on the type of impression materials used. The pressure is not equal during the elastification of the materials. It decreases by almost $50 \%$ during the pressure of $0.5 \mathrm{~kg} .{ }^{6}$ In a similar study, with a pressure of $1 \mathrm{~kg} / \mathrm{cm}^{2}$ the decrease was more than $80 \%{ }^{7}$

Selection of impression materials depends on the anatomical features of the prosthetic field. Hard, thermoplastic and silicon impression materials may be used for border molding. ${ }^{8,9}$ Thermoplastic materials include impression compound, waxes and wax masses. They all have a certain operating temperature range. ${ }^{10,11}$ According to Voronov, they can be classified as reversible and irreversible. ${ }^{12}$ Silicon impression materials for border molding are a separate group, having prolonged manipulation time and appropriate viscosity which allows the performance of the functional tests. ${ }^{13,14}$

The most commonly applied tests are the Herbst tests for border molding. ${ }^{15}$ Determination of the boundary of the prosthesis is influenced by anatomical structures - muscles, muscular and soft tissue gripping. ${ }^{16,17}$ In the distal region, the transverse fold is located in the paratuberal space to facies infratemporalis maxillae. An asymmetry between the left and right halves of upper and lower jaws has been established. ${ }^{18,19}$

After border molding procedure, the negative pressure is created between the custom tray and the prosthetic field. This is an informal indication for a good impression.

\section{AIM}

To compare the negative pressure created after border molding procedure with different impression materials.

\section{MATERIALS AND METHODS}

Thirty-five patients (17 men and 18 women) aged 51 to 87 years with a completely edentulous upper jaw were examined.

Two groups of impression materials were evaluated thermoplastic and elastomers. We used four different brands:

- Detaseal function - additive silicone for border molding

- Sta-seal F - condensation silicone for border molding

- GC Iso functional sticks - synthetic resin for border molding

- Kerr Impression compound green sticks for border molding

A new clinical method was created for negative pressure measurement after border molding procedure. For this purpose, a special custom tray from a light-curing base plate with palatal adapter was made. This was $90^{\circ}, 7 \mathrm{~mm}$ metal adapter, which was fixed to the midline on the palatal slope. For its fixation, a $0.7-\mathrm{mm}$ wire was used for the retentions in the base plate. With this adaptor, it was possible to link the custom tray and a pump for pressure. The small distance between the base plate and the adaptor was filled with hot technical silicone (Figs 1, 2).

A combined pressure pump was used to create and measure the negative pressure. The maximum value was 3
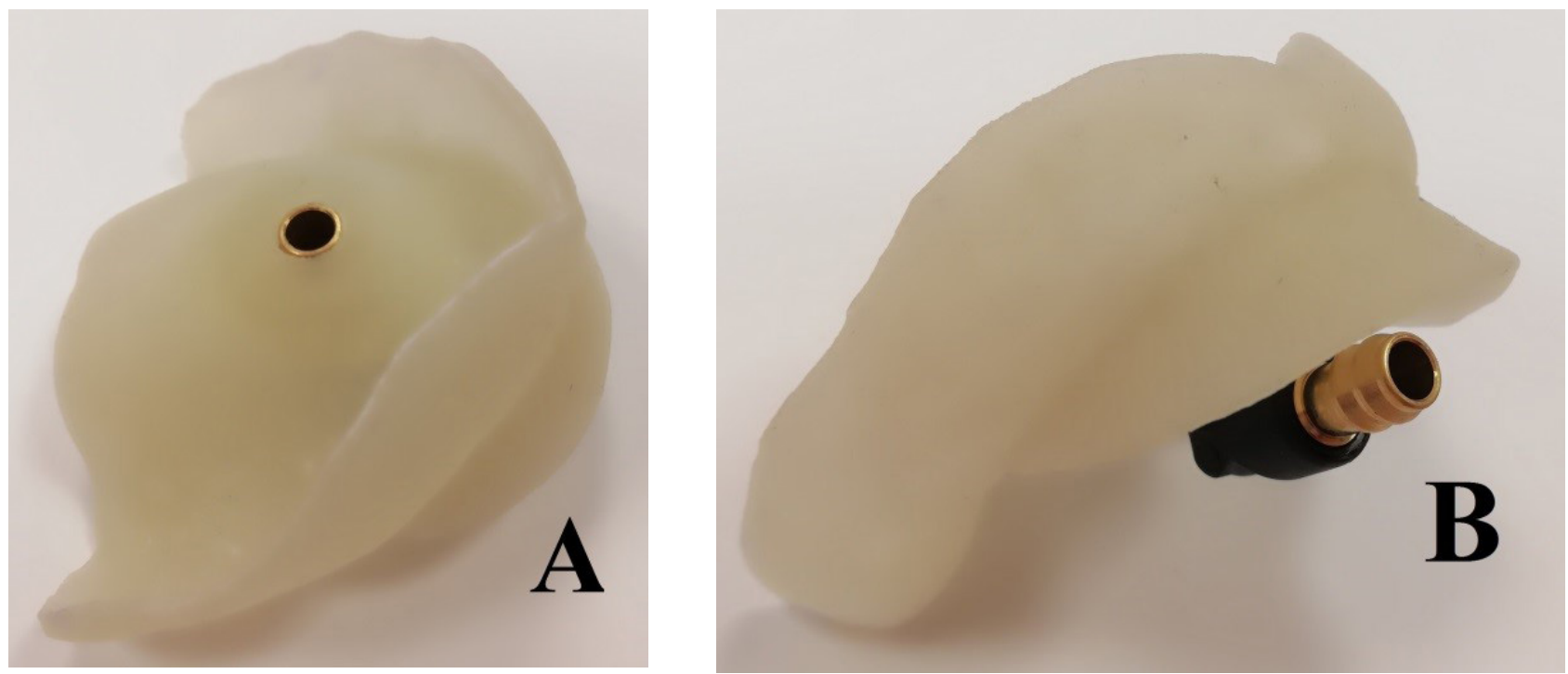

Figure 1. Internal palatal surface (A) and side view (B) of the designed custom tray. 

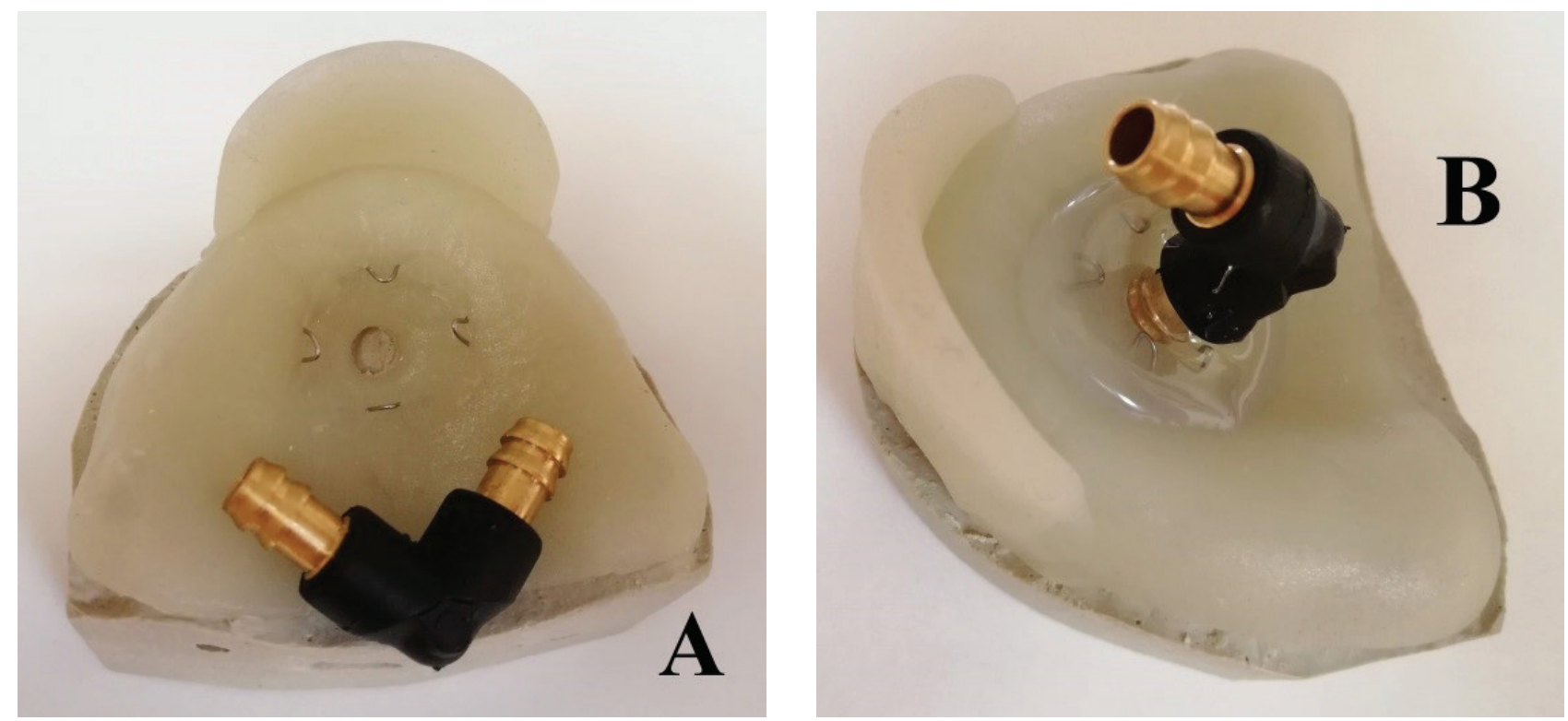

Figure 2. Palatal surface with mechanical retentions before (A) and after (B) the adapter fixation.

bars for positive pressure and - 1 bar for negative pressure. The working part was connected with a $7-\mathrm{mm}$ plastic tube which was the connection between the pump and the custom tray (Fig. 3).

For each patient, four individual impression trays were made with a palatal adapter. Following chemical disinfection of the elements via Zhivasept rapid, the composition was clinically tested. For border molding, the functional tests of Herbst were used.

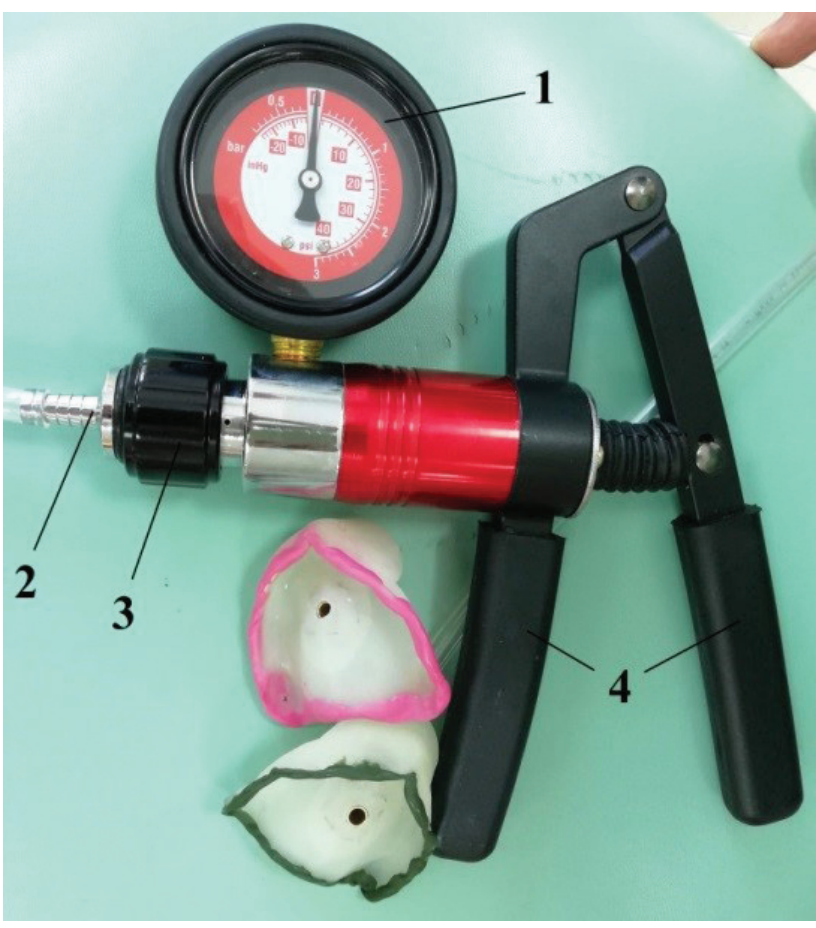

Figure 3. A combined pressure pump: 1 - pressure gauge; 2 working part; 3 - ring to change the operating mode (positive or negative); 4 - handles.
For all materials the following protocol was followed:

1. Applying the impression material along the edge of the individual tray;

2. Insertion, positioning and performance of the Herbst functional tests;

3. Waiting for the elasticity or hardening of the material;

4. Assembling the clinical unit for negative pressure measurement;

5. Measuring the negative pressure, which was created between the custom tray and the prosthetic field, and recording the result;

6. Releasing the individual impression tray from the patient's mouth (Fig. 4).

\section{RESULTS}

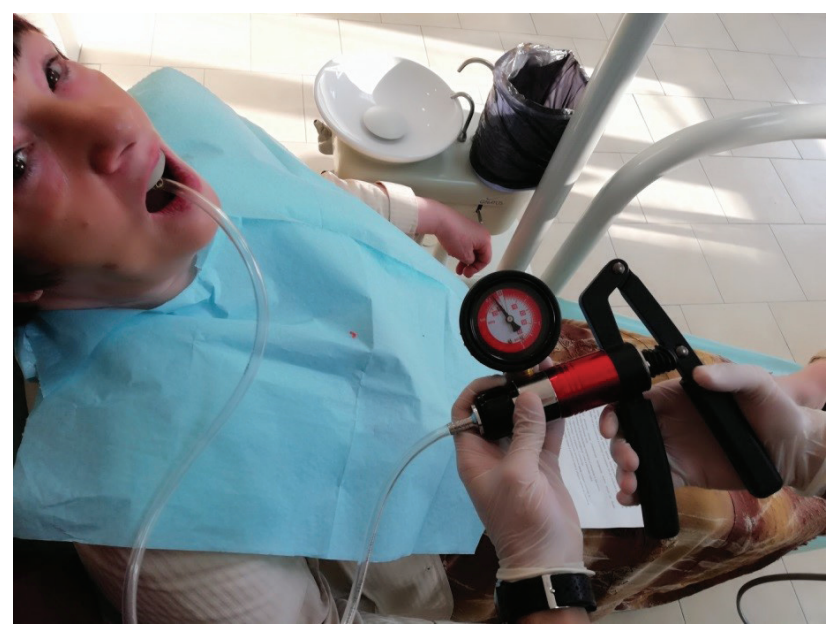

Figure 4. Clinical setup of vacuum measurement after border molding of the custom tray of complete edentulous upper jaw. 


\section{Detaseal function (Detax)}

The tested additive silicone had an easy clinical protocol mixing and application, shaping without any unnecessary effort from the patient. The working time is 5-6 min., which is absolutely enough for border molding procedure. There were difficulties in keeping it on the edge of the custom tray, and part of the alveolar ridge was also printed. After the procedure the extra parts were precisely cut (Fig. 5).

After a clinical border molding, a minimum negative pressure value of -0.2 bar and a maximum of -0.5 bar was

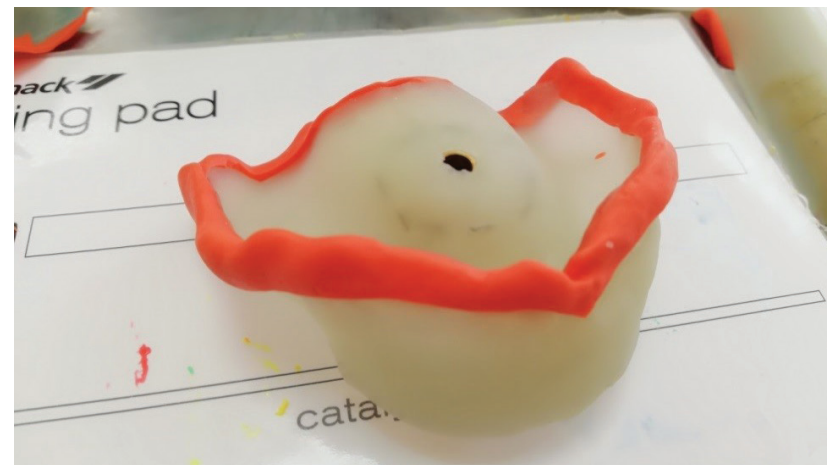

Figure 5. Custom tray after border molding with additive silicone Detaseal function.

measured.The average calculated value was -0.34 bar.

\section{Sta-seal $f($ Detax)}

Condensation silicone due to its moderate rigidity allowed mixing both with a wide spatula on a paper block and between the fingers of the clinician. Functional tests were easily performed and in timely fashion. The material, however, due to the average viscosity flow, also covered part of the alveolar ridge. Again the extra parts were cut (Fig. 6).

The minimum set value of the negative pressure for the condensation silicone test is -0.2 bars, the maximum is -0.6 bars. The average value was -0.36 bars.

\section{GC Iso functional sticks (GC)}

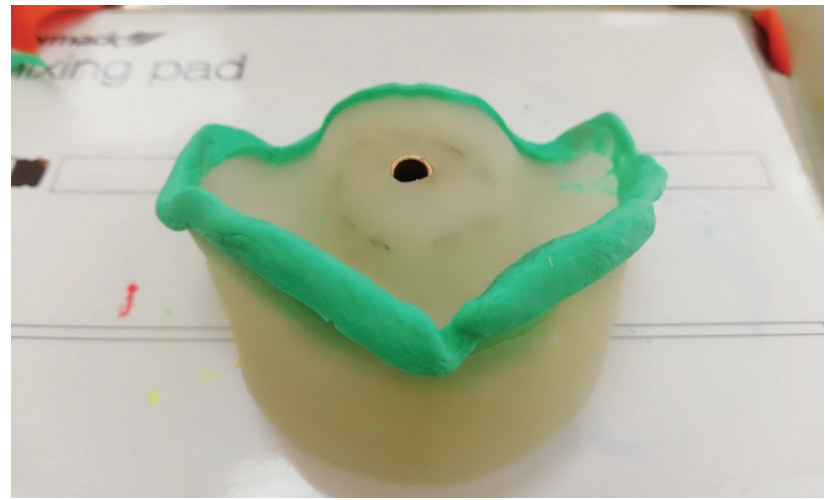

Figure 6. The custom tray after border molding with condensation silicone Sta-seal $\mathrm{f}$.
The synthetic resin showed very good manipulative properties. After heating, it became sticky and plastic, allowing it to be easily and finely applied to the edge of the custom tray. After performing the Herbst tests, a very good shape of the edge was observed without protruding the material to the prosthetic field (Fig. 7).

After the clinical measurement of the negative pressure created by the border molding with the synthetic resin, a minimum value of -0.1 bar (on a highly resorbed alveolar ridge) and a maximum value of -0.55 bar were recorded.

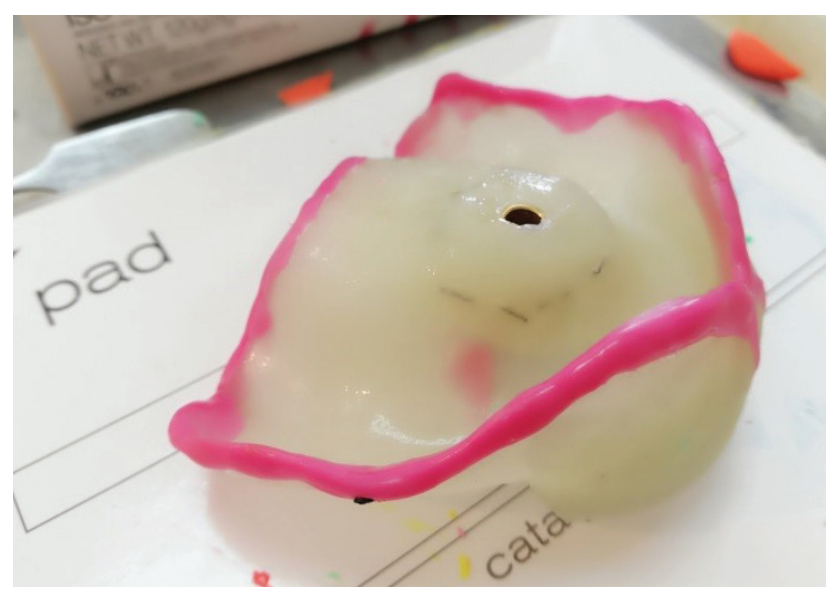

Figure 7. The custom tray after border molding with synthetic resin GC Iso functional sticks.

The average value for this material is -0.38 bar.

\section{Impression compound green stick (Kerr)}

The impression compound showed good manipulative qualities. Unlike the synthetic resin, it was not very sticky and covered a wider layer. The greater rigidity of the material required a difficult performance of the functional tests. The impression compound was formed only on the edges of the custom tray, with a slight protrusion into the area of the alveolar ridge (Fig. 8).

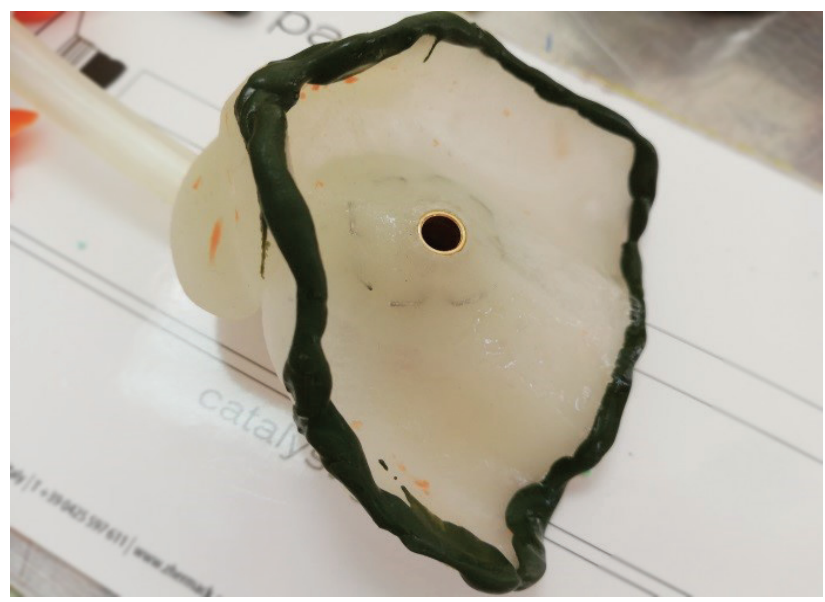

Figure 8. A custom tray after border molding procedure with Impression compound green sticks. 
After clinically shaping and measuring the resulting negative pressure, a minimum value of -0.2 bars and a maximum value of -0.5 bars were observed. The average value was -0.34 bars.

All results are summarized in Table 1 and Fig. 9.

For the statistical analysis, ANOVA was used, confirmed by an absolute value analysis used to compare the negative results, and a log transformation analysis for greater precision as well as for comparison of negative data.

A statistically significant difference was observed be- tween the two thermoplastic materials - GC Iso functional sticks and Impression compound green sticks. The mean group difference between these materials was 0.049 bars.

There was no statistically significant difference between the other groups of materials. The difference ranges were from 0.007 to 0.041 bars (Table 2).

The clinical protocol of handling the two thermoplastic materials shows some differences. The plasticizer temperature of the synthetic resin GC Iso functional sticks is lo-

Table 1. Descriptive statistics by groups

\begin{tabular}{lllll}
\hline & $\begin{array}{l}\text { GC Iso functional } \\
\text { sticks (GC) }\end{array}$ & $\begin{array}{l}\text { Impression compound } \\
(\text { Kerr })\end{array}$ & Sta-seal f (Detax) & $\begin{array}{l}\text { Detaseal function } \\
(\text { Detax })\end{array}$ \\
\hline Mean & -0.3843 & -0.3357 & -0.3629 & -0.3429 \\
Sd & 0.08 & 0.07 & 0.08 & 0.07 \\
Min. & -0.1 & -0.2 & -0.2 & -0.2 \\
Max. & -0.55 & -0.5 & -0.6 & -0.5 \\
Range & 0.45 & 0.3 & 0.4 & 0.3 \\
\hline
\end{tabular}

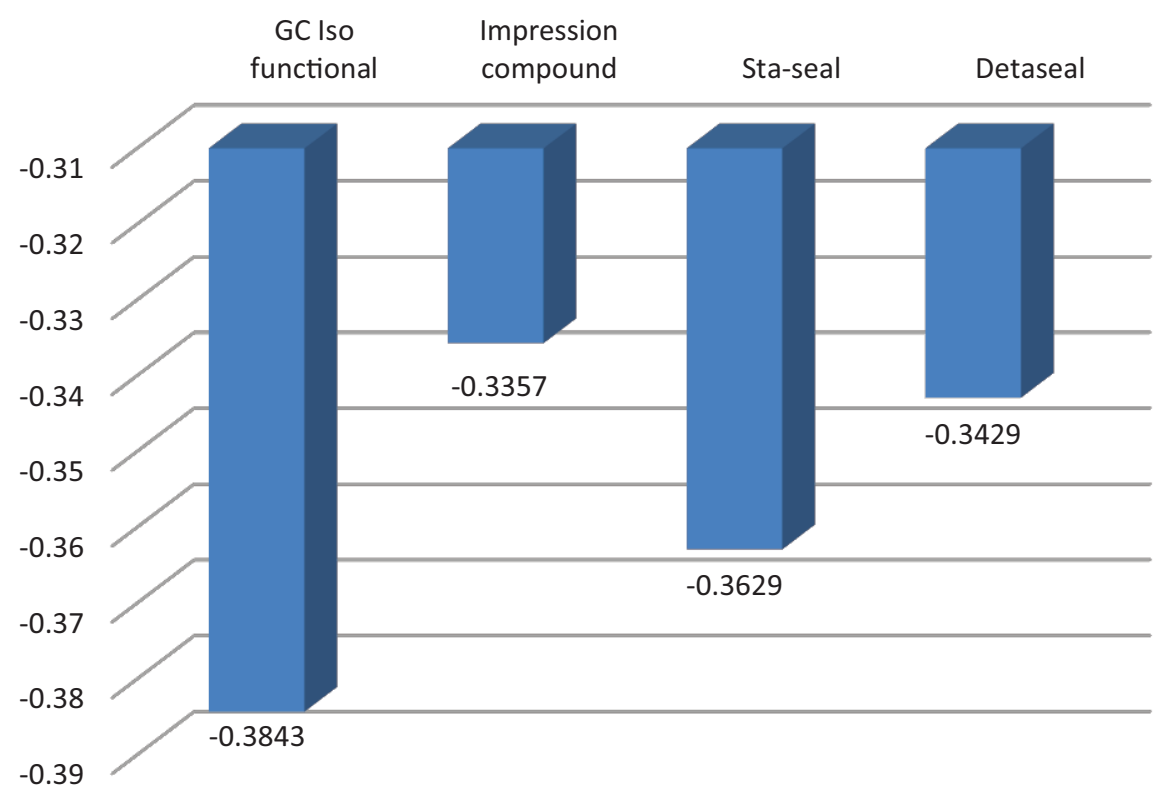

Figure 9. Mean values of the measured clinical negative pressure of the tested materials (bars).

Table 2. Absolute value analysis results

\begin{tabular}{lll}
\hline & $\begin{array}{l}\text { Difference between } \\
\text { group's mean value }\end{array}$ & Statistical significance \\
\hline GC Iso functional sticks - Detaseal function & 0.04142 & No \\
Impression compound - Detaseal function & -0.00714 & No \\
Sta-seal f - Detaseal function & 0.02000 & No \\
Impression compound - GC Iso functional sticks & -0.04857 & Yes \\
Sta-seal f - GC Iso functional sticks & -0.02142 & No \\
Sta-seal f - Impression compound & 0.02714 & No \\
\hline
\end{tabular}


wer (approximately $40^{\circ} \mathrm{C}$ ) and its manipulative properties are retained for a longer period, which is due to the better adaptation of this material. The temperature for impression compound plasticization is higher (approximately $50^{\circ} \mathrm{C}$ ) and under the conditions of the oral cavity it quickly passes to a solid state. These manipulative differences explain partly the resulting statistical difference.

The measured mean negative pressure values created between the prosthetic field and the custom tray showed close values for each patient - with a difference of -0.05 to -0.1 bar. This showed that the anatomical features of the prosthetic field were of great importance.

\section{DISCUSSION}

The creation of the negative pressure with the pump wasn't harmful for the mucosa. ${ }^{1}$ This new method can be used after elastification or hardening of the impression material, therefore we couldn't measure the pressure in different phases of the elastification reaction. ${ }^{6,7}$ The anatomical features of the prosthetic field are very important for the pressure creation. According to our study the difference between the pressure, created with tested impression materials on the same patient was from -0.05 to -0.1 bars. ${ }^{8,9}$ Herbst's tests are appropriate to shape the gingivo-buccal sulcus and to close hermetically the space between the prosthetic field and a custom tray. ${ }^{15-17}$ Unfortunately, we couldn't find a similar study in the literature to compare our pressure values.

\section{CONCLUSION}

Quantitative measurement of negative pressure is entirely possible under clinical conditions. Thermoplastic materials for border molding are retained and formed only along the edge of the custom tray. Silicone impression materials spread not only on the edge of the custom tray, but also on the alveolar ridge.

We couldn't find a similar study in the literature with which to compare our results.

\section{Acknowledgments}

The laboratory study was funded by project No 12/2017, Medical University - Plovdiv, Bulgaria.

\section{REFERENCES}

1. el-Khodary NM, Shaaban NA, Abdel-Hakim AM. Effect of complete denture impression technique on the oral mucosa. J Prosthet Dent 1985; 53(4): 543-9.

2. Gupta A, Singhal P, Negi P. Selective pressure impression technique: an overview. J Evol Med Dent Sci 2014; 3(29): 8110-4.

3. Rihani A. Pressures involved in making upper edentulous impressions. J Prosthet Dent 1981; 46(6): 610-4.

4. Iwasaki M, Kawara M, Inoue S, et al. Pressure dynamics in the trays caused by differences of the various impression materials and thickness of the relief in the maxillary edentulous model. J Prosthodont Res 2016; 60(2): 123-30.

5. Shetty S, Nag PV, Shenoy KK. The selective pressure maxillary impression: A review of the techniques and presentation of an alternate custom tray design. J Indian Prosthodont Soc 2007; 7(1): 8-11.

6. Fouladi TI, Tafti AF, Kamran MHL, et al. In vitro effect of vent size and spacer thickness on pressure produced during maxillary edentulous impression making by different impression materials. JIDAI 2016; 28(1): 40-7.

7. Chopra S, Gupta NK, Tandan A, et al. Comparative evaluation of pressure generated on a simulated maxillary oral analog by impression materials in custom trays of different spacer designs: An in vitro study. Contemp Clin Dent 2016; 7(1): 55-60.

8. Kissov H. [Impression materials and impression techniques for fixed dentures.] Sofia: Index; 1998: 31-50. (In Bulgarian)

9. O'Brien WJ, editor. Dental materials and their selection. Chicago, Berlin, Tokyo: Quintessence Publishing Co, Inc; 2002: 138-167.

10. Starcke E. A historical review of complete denture impression materials. J Am Dent Assoc 1975; 91(5): 1037-41.

11. Jayaraman S, Singh BP, Ramanathan B, et al. Fabrication of complete/ partial dentures (different final impression techniques and materials) for treating edentulous patients (Protocol). Cochrane Libr. 2016;(6):1-16.

12. Voronov AP, Lebedenko IY, Voronov IA. [Orthopedic treatment in edentulous patients.] Moscow, MEDpres-inform 2006: 291-2 (In Russian).

13. Detaseal function - instruction for use, 05/2011; Available from: http://www.detax.de.

14. Sta-seal F - instruction for use, 06/2016; Available from: http://www. detax.de.

15. Popov N. [Prosthetic dentistry. Clinical prosthetics.] Sofia: Medicina y fizkultura; 1999: 221-230 (In Bulgarian).

16. Kaur S, Datta K, Gupta R. Comparative analysis of the retention of maxillary denture base with and without border molding using zinc oxide eugenol impression paste. Indian J Dent 2016; 7(1): 1-12.

17. Lindhe JE, Bressan D, Cecchinato E, et al. Bone tissue in different parts of the edentulous maxilla and mandible. Clin Oral Implants Res 2013; 24(4): 372-7.

18. Slavchev D. [Reproduction of the arch of upper complete denture after analysis of frontal teleroentgenography.] [PhD dissertation] Plovdiv, Bulgaria: Medical University of Plovdiv; 2005 (In Bulgarian).

19. Filchev D. [Graphical and computer design of the distal teeth of complete dentures.] [PhD dissertation] Sofia, Bulgaria, 2013 (In Bulgarian). 


\title{
Клиническое измерение отрицательного давления после процедуры формирования фрункциональных краёв индивидуальной ложки
}

\author{
Добромира А. Шопова, Диян Славчев \\ Кафедра ортопедической дентальной медииины, Факультет дентальной медицины, Медицинский университет - Пловдив, Пловдив, Болгария
}

Адрес для корреспонденции: Добромира А. Шопова, Кафедра ортопедической дентальной медицины, Факультет дентальной медицины, Медицинский университет - Пловдив, бул. „Христо Ботев“ №3, 4000 Пловдив, Болгария; E-mail: dent.shopova@gmail.com; Teл.: +359 887417078

Дата получения: 14 ноября 2019 Дата приемки: 16 января 2020 Дата публикации: 30 сентября 2020

Образец цитирования: Shopova DA, Slavchev D. Clinical negative pressure measurement after border molding procedure. Folia Med (Plovdiv) 2020;62(3):578-84. doi: 10.3897/folmed.62.e48464.

\section{Резюме}

Введение: Формирование функциональных краёв индивидуальных ложек является важным этапом в лечении беззубой челюсти, которое определяет стабильность протеза в покое и во время операции. Твёрдые, термопластичные и силиконовые литейные материалы могут быть использованы для функционального литья. После процедуры функционального формирования создаётся отрицательное давление между индивидуальными ложками и протезным полем. Это можно принять за косвенный показатель высокого качества работы.

Цель: Сравнить отрицательное давление, создаваемое после процедуры функционального формования, с различными материалами для литья.

Материалы и методы: Обследовано 35 пациентов (17 мужчин и 18 женщин) в возрасте от 51 до 87 лет с совершенно беззубой верхней челюстью. Был разработан новый метод измерения отрицательного давления. Мы использовали специальную индивидуальную ложку с адаптером нёба и вакуумным насосом. Были испытаны две группы литейных материалов: термопластичные (Kerr impression compound green sticks, GC Iso functional sticks) и силиконы (Detaseal function, Sta-seal f). Статистический анализ был выполнен с использованием ANOVA, что подтверждено анализом абсолютных значений для сравнения отрицательных результатов и анализа логарифмического преобразования для большей точности, а также для сравнения отрицательных данных.

Результаты: Статистически отрицательное различие было обнаружено между двумя термопластичными материалами - GC Iso functional sticks и Impression compound green sticks. Средняя групповая разница между этими материалами составила 0,049 бар. Статистически значимого различия между другими группами материалов обнаружено не было.

Заключение: Количественное измерение отрицательного давления, создаваемого между индивидуальными ложками и протезным полем, вполне возможно в клинических условиях.

\section{Ключевые слова}

беззубая верхняя челюсть, отрицательное давление 